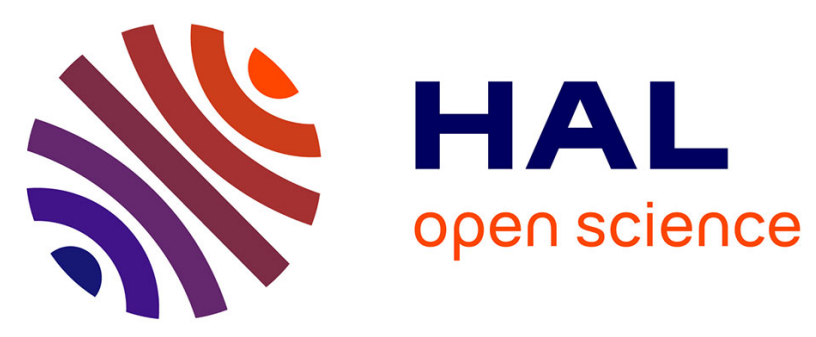

\title{
The host range of the Eucalyptus Weevil, Gonipterus "scutellatus" Gyllenhal (Coleoptera: Curculionidae), in South Africa
}

\author{
Solomon Newete, Rolf Oberprieler, Marcus Byrne
}

\section{To cite this version:}

Solomon Newete, Rolf Oberprieler, Marcus Byrne. The host range of the Eucalyptus Weevil, Gonipterus "scutellatus" Gyllenhal (Coleoptera: Curculionidae), in South Africa. Annals of Forest Science, 2011, 68 (5), pp.1005-1013. 10.1007/s13595-011-0108-9 . hal-00930676

\section{HAL Id: hal-00930676 https://hal.science/hal-00930676}

Submitted on 1 Jan 2011

HAL is a multi-disciplinary open access archive for the deposit and dissemination of scientific research documents, whether they are published or not. The documents may come from teaching and research institutions in France or abroad, or from public or private research centers.
L'archive ouverte pluridisciplinaire HAL, est destinée au dépôt et à la diffusion de documents scientifiques de niveau recherche, publiés ou non, émanant des établissements d'enseignement et de recherche français ou étrangers, des laboratoires publics ou privés. 


\title{
The host range of the Eucalyptus Weevil, Gonipterus "scutellatus" Gyllenhal (Coleoptera: Curculionidae), in South Africa
}

\author{
Solomon W. Newete • Rolf G. Oberprieler • \\ Marcus J. Byrne
}

Received: 18 May 2010 / Accepted: 1 February 2011 / Published online: 1 July 2011

(C) INRA and Springer Science+Business Media B.V. 2011

\begin{abstract}
- Introduction The Eucalyptus Weevil (Gonipterus "scutellatus" Gyllenhal) is a notorious pest of eucalypt plantations around the world, but its host range differs across its area of introduction, which may be due to it being a complex of several cryptic species.

- Objectives The performance of the weevil was tested on 14 Eucalyptus and one Syzygium species in the laboratory and the field in South Africa.

- Results The Weevil exhibited different levels of polyphagy, depending on how the host plants were presented: as bouquets or sleeved branches, in choice or no-choice combinations or in the open field. The fundamental host range in the laboratory was found to be broader than the realized host range in the field. Eucalyptus smithii was found to be the preferred host while Eucalyptus saligna and the native Syzygium myrtifolia were immune to both feeding and oviposition. Adult feeding and oviposition were more selective in the field, and the larvae were found to be less discriminating than the adults.

- Conclusions The weevil is shown to have a narrow host range within two sections of the subgenus Symphyomyrtus, a finding that could contribute to resolution of the taxonomy of the genus Eucalyptus. Further, it suggests that
\end{abstract}

Handling Editor: François Lieutier

S. W. Newete $(\square) \cdot$ M. J. Byrne

School of AP\&ES, University of the Witwatersrand,

Johannesburg 2050, South Africa

e-mail: solomon.newete@students.wits.ac.za

R. G. Oberprieler

Zimmerman Fellow,

CSIRO Ecosystems Sciences,

GPO Box 1700, Canberra, Australia countries that already have the pest may be susceptible to introductions of additional Gonipterus species.

Keywords Host preference $\cdot$ Host specificity. Realized and fundamental host range $\cdot$ Resistant species

\section{Introduction}

There are over 700 species of Eucalyptus native to Australia (Brooker 2000). The outstanding qualities of these trees for the pulp and paper industry, along with their ability to grow fast and thrive in a wide variety of environmental conditions, have made eucalypt plantations the fastest expanding sector of industrial forestry in the world (Wingfield et al. 2008). The demand for its pulp and wood has been growing at a rate of $11.2 \%$ annually since the 1980s (Campinhos 1999), spreading eucalypt trees widely across the planet. The first introduction of eucalypts into South Africa was in the late nineteenth century, when they were imported to provide mining poles, and by 1940 about 149 species were already established (Forsyth et al. 2004). Production of these trees increased, particularly after the requirement for eucalypt wood for pulp mills grew while the demand for props by the mining sector decreased after the 1970s (Morris 2008). Currently, ca. 700,000 ha of the 1.4 million ha of plantations in the country comprise eucalypts (Gebeyehu et al. 2005). Although the selection of Eucalyptus species for commercial plantations has been under progressive change, from the 1980s onwards the main species planted remained either pure stands of Eucalyptus nitens, Eucalyptus macarthurii, Eucalyptus grandis, Eucalyptus dunnii and Eucalyptus smithii or hybrids of E. grandis with E. nitens, Eucalyptus urophylla and Eucalyptus camaldulensis (Morris 2008). 
Compared with the native populations of eucalypts, the introduced species escape from large numbers of native coevolved insects and pathogens and suffer little damage when planted outside their place of origin (Withers 2001). Of the few insect pests known to attack eucalypts in South Africa, the Eucalyptus Weevil (Gonipterus scutellatus Gyllenhal) is the most severe defoliator (Gebeyehu et al. 2005). This weevil species was first introduced accidently into South Africa in 1916 and rapidly became a pest causing severe damage in eucalypt plantations (Mally 1924; Tooke 1953). According to these early studies, Eucalyptus viminalis, Eucalyptus punctata and Eucalyptus globulus are the most susceptible species, with E. viminalis considered the beetle's favourite (Mally 1924; Tooke 1953). In many other literature reviews, E. globulus and E. viminalis are identified as the most preferred host plants of the Eucalyptus Weevil (Millar et al. 1998; Hanks et al. 2000; Loch 2008). However, the host preference of the weevil is not exactly the same in different countries (Table 1) and a marked difference in host range was found in a native population of $G$. scutellatus in Tasmania by Clarke et al. (1998), who recorded oviposition to preferably take place on three "peppermint" species of Eucalyptus (Eucalyptus pulchella, Eucalyptus tenuiramis and Eucalyptus amygdalina) while E. globulus and E. viminalis were the least-favoured oviposition hosts.

As already suspected by Loch (2008), it is now known that G. "scutellatus" actually comprises a complex of at least ten very similar (largely cryptic) species that have been confused in all previous literature. A revision of this complex and clarification of the taxonomy and nomenclature of its various species (Oberprieler, in preparation) as well as a molecular analysis of the complex (Mapondera et al., in preparation) are in progress. From these studies, it is clear that different species of the G. scutellatus complex have been introduced to Africa, America and Europe, whereas the true G. scutellatus appears restricted to Tasmania and is not introduced anywhere in the world. Species names are available for some of the introduced species but not for the common species in South Africa, which turned out to be undescribed. Further, the species studied by Clarke et al. (1998) in Tasmania actually is Gonipterus notographus Boisduval, which does not belong to the G. scutellatus complex. It is, thus, evident that the variation in host preference recorded in different countries is at least in part due to different species of Gonipterus being involved. In South Africa, assessments of host range were made on the assumption of only a single species being present in the country, although Tooke (1953) early on suspected that more than one species of Gonipterus might have been introduced. Evidence from recent molecular studies (Echeveri et al. 2007) indicates that in fact two species of Gonipterus are present in South Africa, although neither the identity of the second species nor its distribution, origin and time of introduction are as yet established. The common species in South Africa is, therefore, here referred to as G. "scutellatus".

Apart from the early studies of host range of $G$. "scutellatus" in South Africa by Mally (1924) and Tooke (1953), based on field observations in the south-western Cape Province, there is little new information available on its host range and preference among the Eucalyptus species in South Africa. In view of the changed composition of eucalypt plantations in the country and the recent insights into the taxonomy of Gonipterus, this research was conducted with the objective of investigating the host preferences of G. "scutellatus" in field and laboratory trials and identifying its host range in South Africa, so as to assist selection of tree species resistant to the weevil in the forestry industry.

Table 1 Difference in susceptibility of eucalypt species to Gonipterus "scutellatus" in different geographical regions

\begin{tabular}{lll}
\hline Country of introduction & Preferred host range of eucalyptus weevils & References \\
\hline California (southern and central) & Eucalyptus globulus, E. viminalis and E. tereticornis & Hanks et al. (2000) \\
Chile (San Felipe region) & E. globulus spp. globulus, E. camaldulensis, E. & Huerta-Fuentes et al. (2008) \\
& viminalis, E. robusta, & FAO (2007) \\
Eucalyptus punctata, Eucalyptus maidenii and Eucalyptus smithii & FAO (2007) \\
Spain & E. globulus spp. globulus & FAO (2007) \\
Eadagascar & Elobulus spp. globulus, E. obliqua, E. longifolia, & FAO (2007) \\
Mauritius & Eucalyptus grandis and Eucalyptus propinqua & FAO (2007) \\
Kenya & E. uringera and E. camaldulis, E. punctata, E. globulus spp. globulus, & Mally (1924) and Tooke (1953) \\
South Africa & E. robusta, E. tereticornis and E. kirtoniana &
\end{tabular}




\section{Materials and methods}

\subsection{Study sites}

The study was conducted in the laboratory at the University of the Witwatersrand, Johannesburg, the Forestry and Agricultural Biotechnology Institute (FABI) nursery at the University of Pretoria and the "Tom Jenkins" eucalypt plantation of the National Zoological Gardens in Pretoria. Fourteen species of Eucalyptus and one southern African species of Myrtaceae, Syzygium myrtifolia, were tested for host preferences of $G$. "scutellatus" in the laboratory and at the FABI nursery $(S$. myrtifolia the only species not at FABI). Ten of these species were also present among the 23 species surveyed in the "Tom Jenkins" plantation during March 2009. The plants at the FABI nursery were about eight years old and grown from seeds of known provenance, imported from the Commonwealth Scientific and Industrial Research Organization in Australia for experimental purposes.

\subsection{Weevil identification}

The ten species of the G. scutellatus complex can be reliably identified only on characters of their male genitalia (Oberprieler, in preparation) and because two species of Gonipterus are now indicated to occur in South Africa (Echeveri et al. 2007; Slippers, personal communication), voucher specimens of weevils collected from Centurion and the "Tom Jenkins" plantation in Pretoria were checked to ensure that the samples used in all laboratory and field experiments represented the same species. These voucher specimens were dissected and their genitalia compared with those of type and other authentic material of Gonipterus in the Australian National Insect Collection in Canberra, Australia. Specimens were also submitted to B. Slippers (FABI, Pretoria) for DNA analysis and further confirmation that only one species was used in all experiments. Both identification procedures verified that all adult specimens used in the trials belonged to the same species, the undescribed G. "scutellatus" that is widespread in South Africa but native to south-eastern Australia.

\subsection{Measurements}

For the laboratory trials, adults and larvae of G. "scutellatus" were collected from eucalypt trees growing wild near the town of Centurion (26 $\left.17^{\prime} 47.7^{\prime \prime} \mathrm{S}, 030^{\circ} 35^{\prime} 46.0^{\prime \prime} \mathrm{E}\right)$. These trees are possibly hybrids and difficult to identify. The larval stage of the weevil consists of four instars, which differ in the size of the head capsule. Body size was used as a crude surrogate for head capsule width and used to classify larvae into four size classes. The proportion of leaf damage inflicted by larvae or adults was estimated by the same experimenter in all trials, on a scale of $0-4$, where $0=$ no feeding, $1=<5 \%, 2=6-25 \%, 3=26-50 \%$ and $4=51-100 \%$, by counting the number of damaged leaves on the branch or bouquet. Adult weevils start feeding from the edges to the centre of the leaf, whereas first-instar larvae mine the leaf surface, leaving characteristic scars, and later instars start biting and shredding the leaf from the margins. The numbers of egg capsules were counted to gauge oviposition levels, and the numbers of adult and larval survivors were counted per branch to record mortality.

Because the weevils prefer younger leaves, branches with freshly growing, undamaged leaves were used in the laboratory experiments (bouquets and sleeves) and only material of known identity was used in any trial. An average of 30 leaves on a branch or bouquet was provided to the weevils in both the sleeve and cage tests.

\subsection{Laboratory tests}

Adult weevils were tested in choice and no-choice tests using cylindrical cages of cotton mesh, $0.63 \mathrm{~m}$ in diameter and $0.6 \mathrm{~m}$ high. Branch tip "bouquets", about $0.3 \mathrm{~m}$ long, were cut, rinsed of potential predators and debris and then placed in flasks of water to maintain turgidity. In no-choice tests, each plant species was caged individually and inoculated with four insects, two males and two females. The number of replicates for each plant species was six. In the paired-choice tests, one branch of E. globulus and one of a "non-target" Eucalyptus species were placed together in a single cage, spanning all non-target plants that sustained some attack during the nochoice tests. Eucalyptus globulus was selected as the target host because it is the common denominator in all host preference lists for G. "scutellatus". Bouquets were changed weekly. This test was run for two weeks.

\subsection{Field confinement tests}

The no-choice tests in the caged bouquets trials were repeated on trees growing in the FABI nursery. A branch tip ( $0.3 \mathrm{~m}$ in length) of six randomly selected trees per species was sleeved in a cylindrical cage of cotton mesh $(0.15 \mathrm{~m}$ diameter and $0.35 \mathrm{~m} \mathrm{high)} \mathrm{on} \mathrm{the} \mathrm{tree.} \mathrm{In} \mathrm{the} \mathrm{test} \mathrm{of} \mathrm{larval}$ survival and feeding, four larvae, a pair each from size classes three and four, was placed in each sleeve, while in the test of adult survival and feeding two males and two females were placed in each sleeve. In the oviposition trials, a pair of adults each was used. These trials were run for 1 week.

\subsection{Field surveys}

The assessment of weevil feeding and oviposition preferences in an open-field test was conducted at the "Tom Jenkins" plantation, where branch tips of $0.5 \mathrm{~m}$ length were 
scored for adult and larval feeding (by counting the number of damaged leaves as a proportion of the number on the sample, an average of 80 leaves per branch) and oviposition. The trees had been planted in plots of 23 eucalypt species, each species in one row per plot containing 12 trees spaced $3 \mathrm{~m}$ apart from the neighbouring trees. Twelve plants from two plots (six from each plot) were randomly selected and surveyed at four points of the compass at head height and above for larval or adult feeding and oviposition. Plants were surveyed in February 2009, towards the emergence of the second generation of weevils.

\subsection{Statistical analysis}

All data in these experiments except for those from the choice tests were transformed to approximate a lognormal
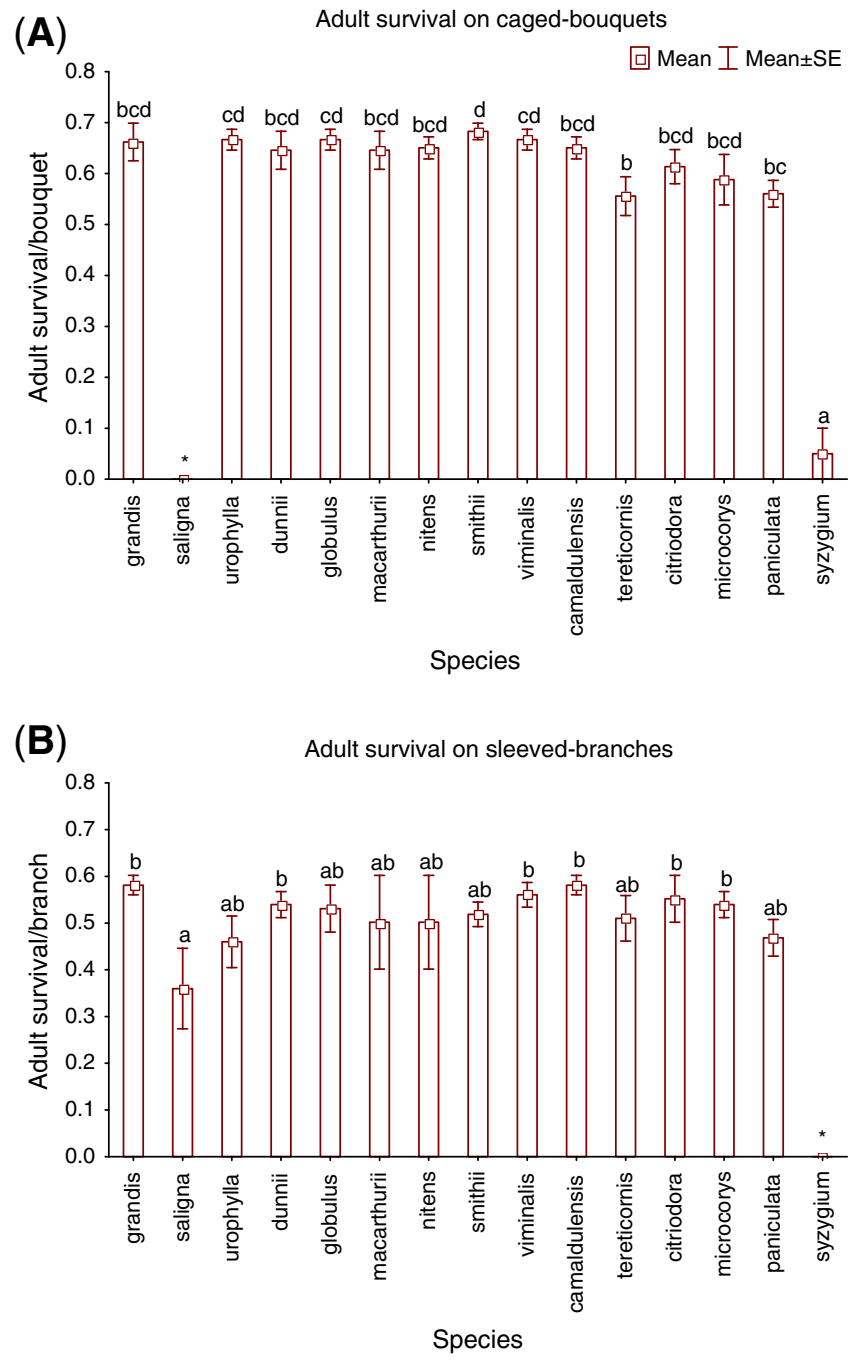

Fig. 1 Adult survival and feeding of Gonipterus "scutellatus" in different treatments on different Eucalyptus species, a adult survival on caged bouquets; $\mathbf{b}$ adult survival on sleeved branches; $\mathbf{c}$ adult feeding on caged bouquets; $\mathbf{d}$ adult feeding on sleeved branches. Means distribution, as $\log _{10}(x+1)$, and subjected to analysis of variance (ANOVA) followed by Duncan's new multiple range test. The results from adult feeding and oviposition choice tests in cages were analysed using a Mann-Whitney non-parametric $U$ test, comparing two independent sets of samples. The Mann-Whitney $U$ test is an alternative to the $t$ test when the data are ordinal, and, unlike the $t$ test, does not assume normality of data distribution. STATISTICA Six Sigma (Statsoft Release 7, 2006) and Microsoft Office Excel 2007 were the computer packages used for data analysis.

\section{Results}

Generally, adult feeding and oviposition in the field were more selective than in the laboratory, while larval feeding

(C)
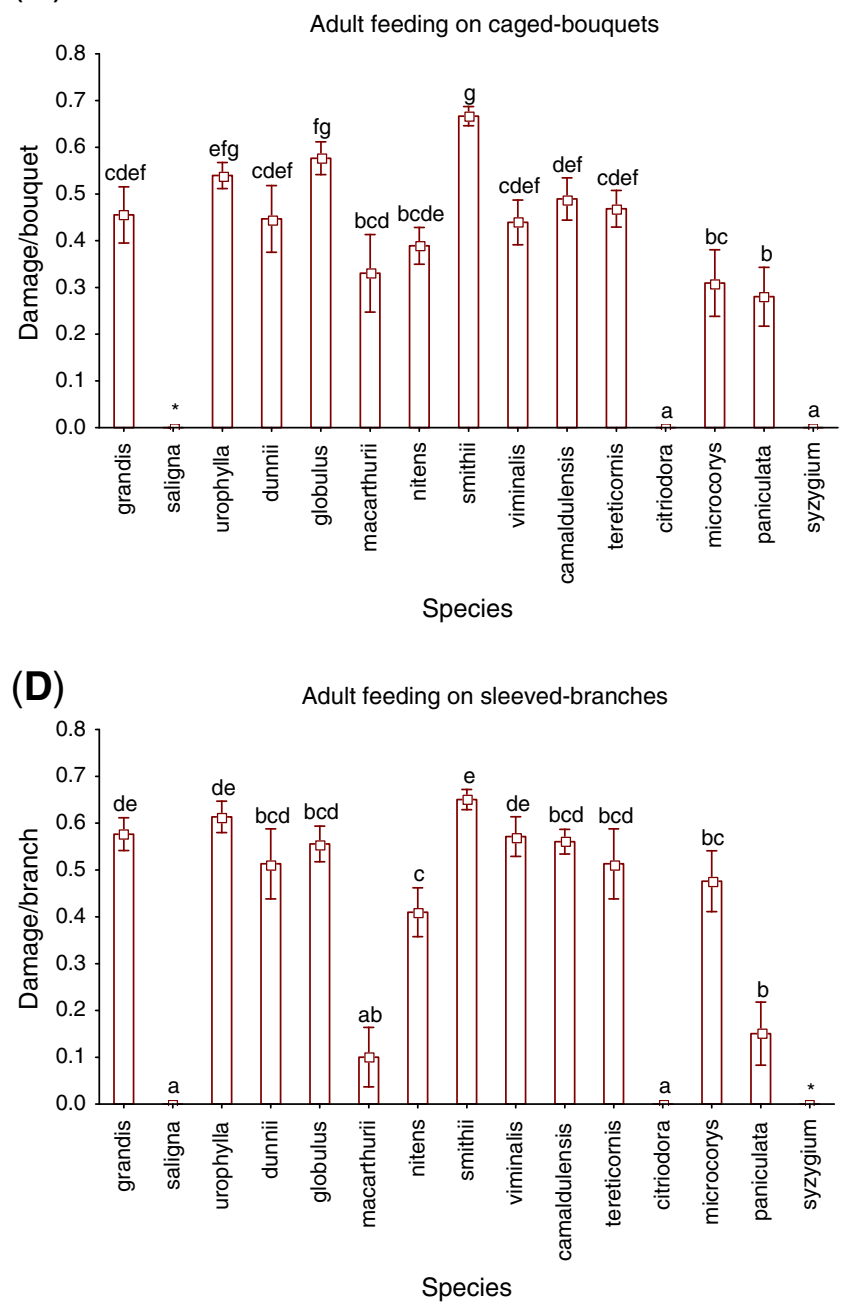

compared by one-way ANOVA and those followed by the same letter(s) are not significantly different $(P>0.05$; Duncan's multiple range test). NB: Asterisk, species not tested but included for continuity with Fig. 2; Yaxis $=\log$-transformed proportion values. $N=6$ trees per species 
was less discriminating than that of the adults but feeding patterns were again less selective in the laboratory than in the field. Oviposition in the field survey was mainly limited to E. smithii, E. grandis, E. viminalis, Eucalyptus dorrigoensis, Eucalyptus scoparia, Eucalyptus nicholii and E. nitens. E. globulus was not present in the field plots, but it nevertheless received few eggs in the caged-bouquet trial in the laboratory. The weevil's overall performance (feeding, survival and oviposition) was highest on E. smithii and not on E. globulus, as reported in the literature. Feeding and oviposition extended to more than one species but was limited to the subgenus Symphyomyrtus, particularly to the sections Maidenaria and Latoangulatae (Table 4).

\subsection{Laboratory and field confinement tests}

Adult survival was generally high in the caged-bouquet trial, and there was a significant difference in adult survival between the species $\left(F_{(13,70)}=24.60, P<0.001\right)$. Syzyggium myrtifolia was the only plant species on which adult survival was significantly different from all the others, and on Eucalyptus tereticornis it was significantly lower than on E. smithii, E. urophylla, E. globulus and E. viminalis (Fig. 1a). In the sleeved-branch trials, adult survival also showed a significant difference between the test plant species $\left(F_{(14,75)}=7.1761, P<0.001\right)$, though $S$. myrtifolia was not included as it was not present at the FABI nursery where the sleeved-branch trials were conducted (Fig. 1b).

Adult feeding on both the caged bouquets and the sleeved branches was significantly different between tree species $\left(F_{(13,70)}=15.16, P<0.001\right.$ and $F_{(13,70)}=23.57$, $P<0.001$, respectively, Fig. 1c, d). The patterns of adult feeding between the two types of trials generally did not differ much, except that feeding on E. macarthurii in the sleeved-branch test was not significantly different from that on the species on which adults showed no feeding (Fig. 1c, d). Although feeding on E. smithii was not significantly different from that on E. urophylla, E. grandis and $E$. globulus in either test, most weevil damage was recorded in both trials on this species. Feeding on E. smithii was significantly greater on all species except $E$. urophylla and E. globulus in the caged-bouquet trials (Fig. 1c) and on all species except $E$. grandis, E. viminalis and E. urophylla in the sleeved-branch tests (Fig. 1d).

Larval feeding preferences in the sleeved-branch trials showed significant differences between tree species $\left(F_{(13,70)}=\right.$ 12.75, $P<0.001$ ) (Table 2). E. tereticornis and Eucalyptus citriodora received the most feeding damage, which was significantly greater than that on E. dunnii, E. macarthurii, E. nitens, E. smithii, E. paniculata and Eucalyptus saligna but not from that on the remaining species (Table 2). In contrast, larval feeding in the field survey showed that $E$. smithii, E. grandis and E. viminalis sustained the most
Table 2 Host preference of Gonipterus "scutellatus" larvae for different Eucalyptus species as determined by feeding intensity in field trials, on sleeved branches and in open-field plantation survey

\begin{tabular}{lll}
\hline \multirow{2}{*}{ Test plants } & \multicolumn{2}{l}{ Mean larval damage $(95 \% \mathrm{CI})^{\mathrm{a}}$} \\
\cline { 2 - 3 } & Sleeved branch & Plantation survey \\
\hline Eucalyptus grandis & $4.1(3.1,5.3) \mathrm{d}, \mathrm{e}$ & $4(4,4) \mathrm{g}$ \\
Eucalyptus saligna & $0 \mathrm{a}$ & $1.1(0.3,0.3) \mathrm{a}, \mathrm{b}$ \\
Eucalyptus urophylla & $4.6(4.1,5.2) \mathrm{d}, \mathrm{e}$ & - \\
Eucalyptus dunnii & $2.2(1.4,3.4) \mathrm{b}$ & - \\
Eucalyptus globulus & $4.4(3.6,5.5) \mathrm{d}, \mathrm{e}$ & - \\
Eucalyptus macarthurii & $2.2(1.4,3.4) \mathrm{b}$ & - \\
Eucalyptus nitens & $2.5(1.9,3.1) \mathrm{b}, \mathrm{c}$ & $0 \mathrm{a}$ \\
Eucalyptus smithii & $3.3(2.8,3.9) \mathrm{c}, \mathrm{d}$ & $4(4,4) \mathrm{g}$ \\
Eucalyptus viminalis & $4.4(3.6,5.5) \mathrm{d}, \mathrm{e}$ & $3.7(3.0,4.5) \mathrm{g}$ \\
Eucalyptus camaldulensis & $3.9(3.1,5.0) \mathrm{d}, \mathrm{e}$ & $2.2(1.6,3.1) \mathrm{d}, \mathrm{e}, \mathrm{f}$ \\
Eucalyptus tereticornis & $5.0(5.0,5.0) \mathrm{e}$ & $2.2(1.5,3.0) \mathrm{d}, \mathrm{e}, \mathrm{f}$ \\
Eucalyptus citriodora & $4.8(4.4,5.3) \mathrm{e}$ & $2.3(1.7,3.1) \mathrm{e}, \mathrm{f}$ \\
Eucalyptus microcorys & $3.7(2.9,4.9) \mathrm{d}, \mathrm{e}$ & $1.8(1.8,1.8) \mathrm{c}, \mathrm{d}, \mathrm{e}, \mathrm{f}$ \\
Eucalyptus paniculata & $3.3(2.1,5.1) \mathrm{c}, \mathrm{d}$ & $0 \mathrm{a}$ \\
Syzygium myrtifolia & - & - \\
\hline
\end{tabular}

NB: Means compared by one-way ANOVA; means in the same column followed by the same letter(s) are not significantly different $(P>0.05$; Duncan's multiple range test)

${ }^{a}$ Back-transformed mean feeding scores estimated by counting the number of damaged leaves on the branch or bouquets on a scale of $0-4$, where $0=$ no feeding, $1=<5 \%, 2=6-25 \%, 3=26-50 \%$ and $4=51-100 \%$ and log transformed; $(-)$ species not present in the plantation. $N=6$ for sleeved branches test and 12 for trees surveyed

(statistically significant) larval damage of all the species tested. Some species, such as E. nitens and E. paniculata, sustained feeding by the larvae on sleeved branches but not in the plantation field survey (Table 2). However, E. saligna was untouched in the sleeved-branch trial, while some leaves in the field survey were slightly damaged but not significantly different from the untouched species (Table 2). Larval survival on sleeved branches also showed significant differences between plant species $\left(F_{(13,70)}=3.70, P<0.001\right)$, and most larvae survived on $E$. urophylla, though not significantly more than on the other species except $E$. nitens, $E$. paniculata and E. saligna, on which larval survival was significantly lowest (Fig. 2).

In the paired-choice test, adult feeding damage was significantly greater on seven species paired with $E$. globulus, only two pairings, of E. saligna and E. citriodora, showing significantly lower feeding and four species showing no significant difference in feeding from that on E. globulus (Table 3). The only test plant not used by the adult weevils in these trials but used by the larvae in both sleeved no-choice trials at FABI and choice trials in the field survey (Table 2) was E. citriodora. In the oviposition 
Larval survival on sleeved-branches

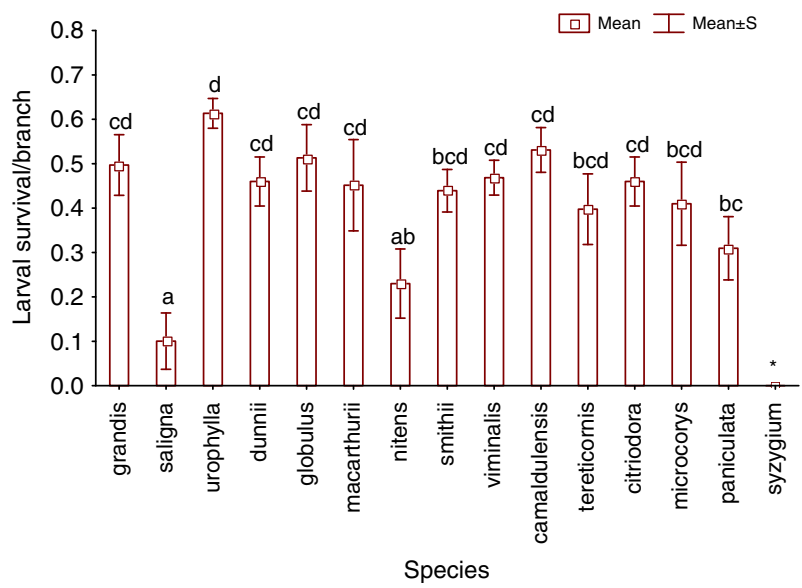

Fig. 2 Larval survival of Gonipterus "scutellatus" on sleeved branches in 7 days. Means compared by one-way ANOVA and those followed by the same letter(s) are not significantly different $(P>0.05$; Duncan's multiple range test). NB: Asterisk, species not tested but included for continuity with Fig. 1; Y-axis = log-transformed proportion values. $N=6$ trees per species

trials, of the nine species pairs that sustained oviposition, only three received significantly more eggs on one of the species, which was never E. globulus (Table 3). In seven of the pairs no eggs were laid on E. globulus, and four of these pairs received no eggs on either of the species. $E$. macarthurii, E. nitens, E. citriodora, E. paniculata and E. saligna received no eggs while $E$. smithii received the most.

\subsection{Field surveys}

There were significant differences in adult feeding between different tree species in the field survey $\left(F_{(22,253)}=31.28\right.$, $P<0.001$ ) (Fig. 3a). Six of the 23 plant species surveyed were not used by the adult weevils, another four that suffered some weevil damage were not significantly different from those that were untouched and showed no oviposition (or statistically the same as none). On the other hand, E. smithii, $E$. grandis and $E$. nitens were the species on which the most statistically significant adult feeding occurred in the field.

Significant differences in oviposition were detected across the tree species $\left(F_{(22,253)}=27.84, P<0.001\right)$ (Fig. 3b). No eggs were deposited on 12 species and the statistical equivalent of none on another three, while $E$. smithii and $E$. grandis received significantly higher numbers of eggs than all other species (Fig. 3b).

\section{Discussion}

The variation between the Eucalyptus species in terms of the weevil's performance is very striking. Some of the
Table 3 Host selection of Gonipterus "scutellatus" adults during paired-choice tests as determined by their mean $( \pm \mathrm{SE})$ feeding intensity and oviposition on different species of Eucalyptus in caged bouquets

\begin{tabular}{|c|c|c|}
\hline \multirow[t]{2}{*}{ Test plant species } & \multicolumn{2}{|l|}{ Caged-bouquet test } \\
\hline & Mean adult feeding ${ }^{\mathrm{a}}$ & Mean oviposition \\
\hline Eucalyptus grandis & $2.5 \pm 0.3 \mathrm{~b}$ & $1.8 \pm 1.3 \mathrm{a}$ \\
\hline Eucalyptus globulus & $1 \pm 0.37 \mathrm{a}$ & $0 \mathrm{a}$ \\
\hline Eucalyptus saligna & $0 \mathrm{a}$ & $0 \mathrm{a}$ \\
\hline E. globulus & $1.5 \pm 0.6 \mathrm{~b}$ & $0 \mathrm{a}$ \\
\hline Eucalyptus urophylla & $3.5 \pm 0.3 \mathrm{~b}$ & $5 \pm 2.0 \mathrm{~b}$ \\
\hline E. globulus & $0.8 \pm 0.3 \mathrm{a}$ & $0 \mathrm{a}$ \\
\hline Eucalyptus dunnii & $3.2 \pm 0.6 \mathrm{~b}$ & $2.3 \pm 0.8 \mathrm{a}$ \\
\hline E. globulus & $1.5 \pm 0.2 \mathrm{a}$ & $1.2 \pm 0.4 \mathrm{a}$ \\
\hline Eucalyptus macarthurii & $0.7 \pm 0.3 \mathrm{a}$ & $0 \mathrm{a}$ \\
\hline E. globulus & $1 \pm 0.37 \mathrm{a}$ & $0.2 \pm 0.2 \mathrm{a}$ \\
\hline Eucalyptus nitens & $1.7 \pm 0.2 \mathrm{~b}$ & $0 \mathrm{a}$ \\
\hline E. globulus & $1 \pm 0 \mathrm{a}$ & $0 \mathrm{a}$ \\
\hline Eucalyptus smithii & $3.7 \pm 0.21 \mathrm{~b}$ & $6.7 \pm 2.6 \mathrm{~b}$ \\
\hline E. globulus & $0.7 \pm 0.5 \mathrm{a}$ & $1 \pm 1 \mathrm{a}$ \\
\hline Eucalyptus viminalis & $3.5 \pm 0.2 \mathrm{~b}$ & $5 \pm 1.9 \mathrm{~b}$ \\
\hline E. globulus & $0.3 \pm 0.3 \mathrm{a}$ & $0 \mathrm{a}$ \\
\hline Eucalyptus camaldulensis & $2.3 \pm 0.4 \mathrm{a}$ & $2.8 \pm 1.3 \mathrm{a}$ \\
\hline E. globulus & $1.7 \pm 0.3 \mathrm{a}$ & $1 \pm 0.8 \mathrm{a}$ \\
\hline Eucalyptus tereticornis & $3.2 \pm 0.3 \mathrm{~b}$ & $3 \pm 1.8 \mathrm{a}$ \\
\hline E. globulus & $0.8 \pm 0.3 \mathrm{a}$ & $0.2 \pm 0.2 \mathrm{a}$ \\
\hline Eucalyptus citriodora & $0 \mathrm{a}$ & $0 \mathrm{a}$ \\
\hline E. globulus & $3 \pm 0.4 \mathrm{~b}$ & $0 \mathrm{a}$ \\
\hline Eucalyptus microcorys & $1.7 \pm 0.3 \mathrm{a}$ & $0.2 \pm 0.2 \mathrm{a}$ \\
\hline E. globulus & $2.2 \pm 0.5 \mathrm{a}$ & $0.2 \pm 0.2 \mathrm{a}$ \\
\hline Eucalyptus paniculata & $1.5 \pm 0.4 \mathrm{a}$ & $0 \mathrm{a}$ \\
\hline E. globulus & $1 \pm 0.6 \mathrm{a}$ & $0 \mathrm{a}$ \\
\hline Syzygium myrtifolia & - & - \\
\hline E. globulus & - & - \\
\hline
\end{tabular}

NB: Means compared by non-parametric Mann-Whitney $U$ test; those paired tests in the same column followed by the same letter(s) are not significantly different $(P>0.05$; Mann-Whitney $U$ test $)$

${ }^{\text {a }}$ Feeding categories estimated by counting the number of damaged leaves on the branch or bouquet on a scale of $0-4$, where $0=$ no feeding, $1=<5 \%, 2=6-25 \%, 3=26-50 \%$ and $4=51-100 \% ;(-)$ species not tested (species indicated as immune from the no-choice trial). $N=6$ 
(A) Adult feeding in plantation survey
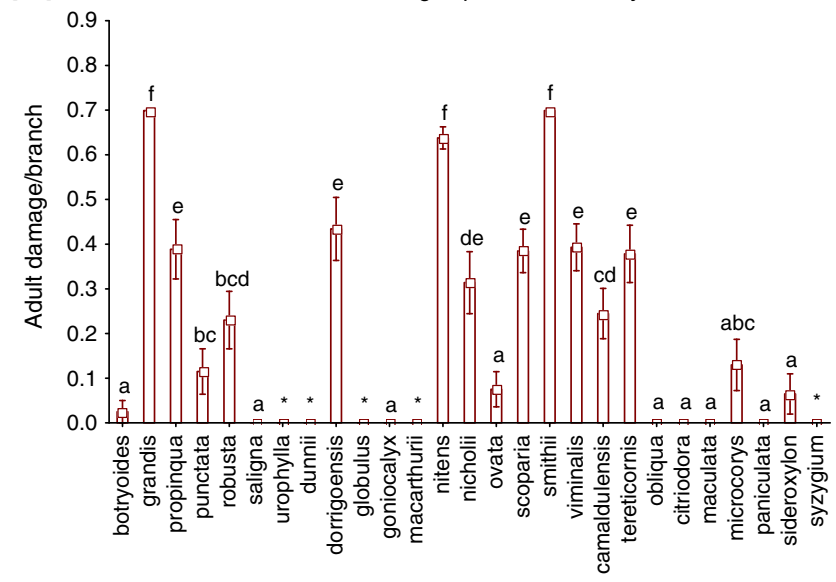

(B)

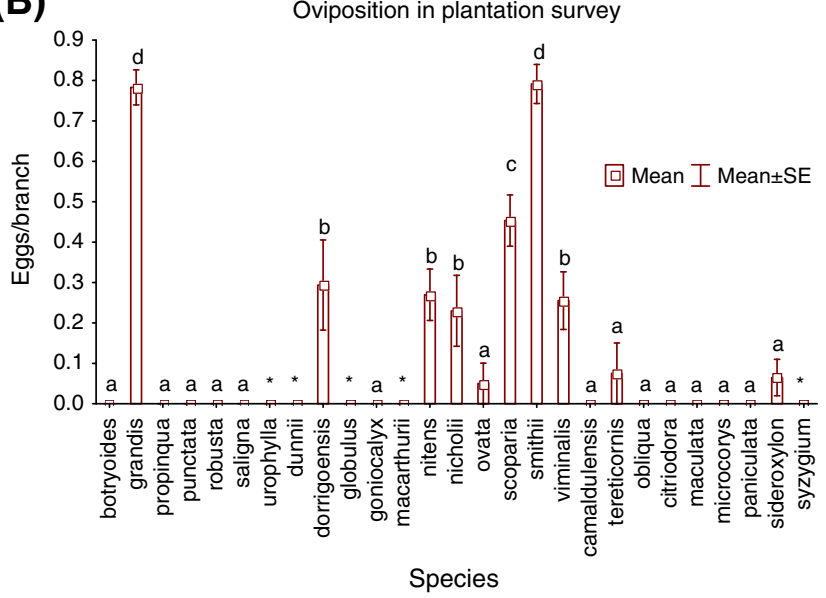

Fig. 3 Differences in adult Gonipterus "scutellatus" feeding and oviposition on Eucalyptus species growing in a plantation, in a natural, multi-choice environment; $\mathbf{a}$ mean adult damage and $\mathbf{b}$ mean number of eggs deposited per branch. Means compared by one-way ANOVA and those followed by the same letter(s) are not significantly different $(P>0.05$; Duncan's multiple range test). NB: Asterisk, species not present in the plantation but included for continuity with previous figures; $Y$-axis $=\log$-transformed proportions of damage per branch. $N=12$ trees per species

species were severely damaged while others suffered little or no damage. Most Eucalyptus species have toxic secondary chemical compounds that inhibit herbivore attack (Rapley et al. 2008), such as terpenoids, tannins and other phenolics, which can constitute $40 \%$ of the leaf dry matter (Pass et al. 1998) and may play a role in host selection by the weevils. The Eucalyptus species used in these trials belong to four subgenera. G. "scutellatus" showed a marked preference for primarily one taxonomic group of Eucalyptus. All the plants that sustained larval and adult feeding and oviposition in the laboratory or the field belong to the subgenus Symphyomyrtus and the most preferred hosts on which oviposition and feeding took place to the section Maidenaria, after Brooker (2000). Host plant preference showed a decline from the sections Latoangulatae and Exsertaria to the subgenus Alveolata, while species of the subgenera Eucalyptus and Corymbia are evidently not hosts for this weevil species (Table 4).

Using oviposition measured in the field as the benchmark for host selection, G. "scutellatus" mainly oviposited on Eucalyptus species in the section Maidenaria, with the exception of E. grandis and E. urophylla (Table 4), although for the latter species no field data were available, where weevils were found to be much more discriminating than in the laboratory. Most of the species in the section Latoangulatae supported feeding to some extent or showed little to no attack, as E. saligna, E. punctata and Eucalyptus botryoides. The rest of the tested plants, even though sustaining slight larval or adult damage and in some cases receiving a few eggs in the laboratory trials, supported no oviposition in the field survey. Based on the female host selection criteria, these species are therefore considered either the least preferred or immune to damage by G. "scutellatus". Eucalyptus citriodora and E. maculata in the subgenus Corymbia, E. paniculata and Eucalyptus sideroxylon in the subgenus Symphyomytrus and E. microcorys in the subgenus Alvoelata are some such examples.

Some of the test species in the field survey from the section Latoangulatae, such as Eucalyptus propinqua, E. punctata, E. robusta and E. botryoides, showed adult feeding but did not support oviposition. Since these species were not included in the laboratory trials, their suitability within the physiological host range of G. "scutellatus" was not determined in this study. Nevertheless, they are indicated as preferred hosts of G. "scutellatus" in some literature, for instance E. propinqua in Spain, E. punctata in South Africa (Mally 1924) and Chile (Huerta-Fuentes et al. 2008) and E. robusta in Kenya and Mauritius (FAO 2007). However, the species of Gonipterus tested in those studies were not carefully identified and at least those in Spain and Chile are not the same species as the one in South Africa studied here (Oberprieler, Mapondera et al., in preparation).

The species of Gonipterus assessed in this study (referred to as G. "scutellatus") is native to south-eastern Australia, particularly New South Wales (N.S.W.) and parts of Victoria, but does apparently not occur in Tasmania. All the Eucalyptus species utilised as preferred host plants by this weevil in this study, except E. urophylla, are similarly native to eastern Australia and widely distributed in the weevil's natural range. For instance $E$. smithii occurs in the eastern part of the southern tablelands of N.S.W. and eastern Victoria, E. viminalis in south-eastern Queensland, eastern N.S.W. and north-eastern Victoria as well as in parts of Tasmania and E. scoparia along the border of Queensland 
Table 4 Tree species that supported adult feeding and oviposition in the field survey (taxonomic classification by Brooker 2000)

$A$ adult feeding, $O$ oviposition, $(-)$ no feeding and no oviposition

${ }^{a}$ Adult feeding and oviposition data from caged-bouquet trials since the species were not present in the plantation survey

${ }^{\mathrm{b}}$ Adult feeding not significant from plant species untouched

\begin{tabular}{|c|c|c|c|c|}
\hline Genus & Subgenus & Section & Species & Weevil status \\
\hline Eucalyptus & Symphyomyrtus & Maidenaria & smithii & $\mathrm{A}+\mathrm{O}$ \\
\hline Eucalyptus & Symphyomyrtus & Maidenaria & scoparia & $\mathrm{A}+\mathrm{O}$ \\
\hline Eucalyptus & Symphyomyrtus & Maidenaria & dorrigoensis & $\mathrm{A}+\mathrm{O}$ \\
\hline Eucalyptus & Symphyomyrtus & Maidenaria & viminalis & $\mathrm{A}+\mathrm{O}$ \\
\hline Eucalyptus & Symphyomyrtus & Maidenaria & globulus & $\mathrm{A}+\mathrm{O}^{\mathrm{a}}$ \\
\hline Eucalyptus & Symphyomyrtus & Maidenaria & nitens & $\mathrm{A}+\mathrm{O}$ \\
\hline Eucalyptus & Symphyomyrtus & Maidenaria & nicholii & $\mathrm{A}+\mathrm{O}$ \\
\hline Eucalyptus & Symphyomyrtus & Maidenaria & dunnii & $\mathrm{A}+\mathrm{O}^{\mathrm{a}}$ \\
\hline Eucalyptus & Symphyomyrtus & Maidenaria & macarthurii & $\mathrm{A}+\mathrm{O}^{\mathrm{a}}$ \\
\hline Eucalyptus & Symphyomyrtus & Maidenaria & ovata & $A^{b}$ \\
\hline Eucalyptus & Symphyomyrtus & Maidenaria & goniocalyx & - \\
\hline Eucalyptus & Symphyomyrtus & Latoangulatae & urophylla & $\mathrm{A}+\mathrm{O}^{\mathrm{a}}$ \\
\hline Eucalyptus & Symphyomyrtus & Latoangulatae & grandis & $\mathrm{A}+\mathrm{O}$ \\
\hline Eucalyptus & Symphyomyrtus & Latoangulatae & propinqua & A \\
\hline Eucalyptus & Symphyomyrtus & Latoangulatae & robusta & A \\
\hline Eucalyptus & Symphyomyrtus & Latoangulatae & punctata & A \\
\hline Eucalyptus & Symphyomyrtus & Latoangulatae & saligna & - \\
\hline Eucalyptus & Symphyomyrtus & Latoangulatae & botryoides & $A^{b}$ \\
\hline Eucalyptus & Symphyomyrtus & Exsertaria & tereticornis & A \\
\hline Eucalyptus & Symphyomyrtus & Exsertaria & camaldulensis & A \\
\hline Eucalyptus & Symphyomyrtus & Adnataria & paniculata & - \\
\hline Eucalyptus & Symphyomyrtus & Adnataria & sideroxylon & $A^{b}$ \\
\hline Eucalyptus & Eucalyptus & Eucalyptus & obliqua & - \\
\hline Eucalyptus & Eucalyptus & Pseudophloius & pilularis & - \\
\hline Eucalyptus & Alveolata & - & microcorys & A \\
\hline Eucalyptus & Corymbia & Septentrionales & citriodora & - \\
\hline Eucalyptus & Corymbia & Septentrionales & maculata & - \\
\hline Syzygium & - & - & myrtifolia & - \\
\hline
\end{tabular}

and N.S.W., while E. grandis is widely distributed along the northern coast of N.S.W. and adjacent areas of Queensland and planted in Queensland and N.S.W. (Brooker and Kleinig 1983). Some of the resistant species, such as $E$. saligna, are also found along the eastern Australian coast (Brooker and Kleinig 1983), while E. citriodora naturally occurs in a small area in subtropical Queensland (Chippendale and Johnston 1969). In contrast, E. globulus is native in the eastern and south-eastern parts of Tasmania and a small area in southern Victoria, while E. urophylla is endemic on seven islands in the eastern part of Indonesia (Payn et al. 2007). It is therefore not surprising that the most preferred host plants of $G$. "scutellatus" in this trial are also those species that occur within its natural geographical distribution in Australia, from which both the weevil and the plant species could have been introduced into South Africa.

Unexpectedly, both the laboratory and the field confinement trials showed E. urophylla as one of the preferred hosts of G. "scutellatus". There is no Gonipterus species in Indonesia and no report of such damage on E. urophylla in the region, and no study in the literature has included $E$. urophylla in host specificity tests involving Gonipterus. However, from the results of this study it is likely that $E$. urophylla is at risk of attack from G. "scutellatus" should this weevil species find its way to Indonesia, and possibly also from other Gonipterus species. Field testing of its exact susceptibility in South Africa and elsewhere would indicate the level of that risk.

\section{Conclusions}

The distribution ranges of the Eucalyptus hosts of $G$. "scutellatus" identified in this study correlate well with the native range of this weevil in Australia, suggesting that host preference is a stable character even in historically translocated populations. However, given the historically confused species identity of the eucalyptus weevil in the various countries where it has been introduced, it is of paramount importance in host specificity tests in such countries to establish the correct identity of the relevant species of Gonipterus. 
In line with the recent taxonomic insights into the $G$. scutellatus complex, the results of this study indicate that the research that identified E. globulus and E. viminalis as the most preferred host of Gonipterus, as in Chile or California, dealt with a species of Gonipterus different from the one in South Africa. The different host range of this weevil as assessed by Mally (1924) and Tooke (1953) in South Africa is more difficult to explain. While a second species of Gonipterus is now indicated to occur in South Africa (Echeveri et al. 2007), it is as yet unknown whether this species has been in the country long enough and widely distributed enough to have confounded the results of Mally (1924) and Tooke (1953). A less rigorous assessment of host preferences and regional climatic differences may also account for the different host range identified in South Africa earlier.

Unless G. "scutellatus" is controlled effectively in South Africa, high levels of infestation of Eucalyptus species such as E. smithii, E. urophylla, E. grandis, E. scoparia, E. viminalis and $E$. dorrigoensis could result, leading to economic losses in plantations. In contrast, E. saligna, E. citriodora and E. paniculata are resistant to damage by this weevil and would be the most suitable for use in plantations or for hybridization with susceptible Eucalyptus species from a pest management point of view.

Currently, E. grandis is the main species used to crossbreed with E. urophylla, E. nitens and E. camaldulensis (Morris 2008), but this combination would not alleviate the issue of hybrid susceptibility to G. "scutellatus", and possibly even exacerbate it. In addition, the host preference of the indicated second species of Gonipterus in South Africa requires investigation, along with its current and potential future distribution and interaction with G. "scutellatus". Further, even though G. "scutellatus" is already a pest in South Africa, it is essential to quarantine all eucalypt material imported into the country so as to avoid the introduction of yet another species of the G. scutellatus complex.

Acknowledgements We thank Prof. Mary Scholes for financial assistance, Prof. Ed Witkowski for tirelessly supplying Syzygium plant material, Azmera Debesay for help with field work and Tsedal Ghebremariam for assistance with statistical analysis. The FABI staff, in particular Dr. Bernard Slippers, Wilhelm de Beer and Ryan Nadel, are thanked for support and use of the FABI nursery and Dr. Bernard Slippers also for confirming the conspecificity of the specimens of Gonipterus "scutellatus" used in this study.

\section{References}

Brooker MIH (2000) A new classification of the genus Eucalyptus L'Hér. (Myrtaceae). Austral Syst Bot 13:79-148

Brooker MIH, Kleinig DA (1983) Field guide to eucalypts. Volume 1. Inkata Press, Melbourne, pp 129-213
Campinhos EJR (1999) Sustainable plantations of high-yield Eucalyptus trees for production of fiber: the Aracruz case. New For 17:129-143

Chippendale GM, Johnston RD (1969) Eucalypts: Stan Kelly. Nelson, Camden, $14 \mathrm{p}$

Clarke AR, Paterson S, Pennington P (1998) Gonipterus scutellatus Gyllenhal (Coleoptera: Cuculionidae) oviposition on seven naturally co-occurring Eucalyptus species. For Ecol Manage 110:89-99

Echeveri D, Slippers B, Hurley BP and Wingfield MJ (2007) Population diversity and structure of the Eucalyptus Snout-Beetle, Gonipterus scutellatus (Coleoptera, Curculionidae) in South Africa, Spain, Chile and Uruguay. In: IUFRO WP 2.08.03 Improvement and culture of eucalypts. 'Eucalypts and diversity: balancing productivity and sustainability', Durban, South Africa, 22-26 October 2007

FAO (2007) Forest Pest Species Profile, Gonipterus scutellatus. Available at: http://www.fao.org/forestry/media/13563/1/0/. Accessed 15 May 2009

Forsyth GG, Richardson DM, Brown PJ, Van Wilgen BW (2004) Rapid assessment of the invasive status of Eucalyptus species in two South African provinces. S Afr J Sci 100:75-77

Gebeyehu S, Hurley BP, Wingfield MJ (2005) A new lepidopteran insect pest discovered on commercially grown Eucalyptus nitens in South Africa. S Afr J Sci 101:26-28

Hanks LM, Millar JG, Paine TD, Campbell CD (2000) Classical biological control of the Australian weevil Gonipterus scutellatus (Coleoptera: Curculionidae) in California. Environ Entomol 29:369-375

Huerta-Fuentes A, Chiffelle-Gómez I, Serrano-Garón M, Vázquez-Silva T, Araya-Clericus J (2008) Susceptibility of eucalyptus species to Gonipterus scutellatus and electrophoretic profiles of adult marker proteins. Agrociencia 42:27-334

Loch AD (2008) Parasitism of the eucalyptus weevil, Gonipterus scutellatus Gyllenhal, by the egg parasitoid, Anaphes nitens Girault, in Eucalyptus globulus plantations in south-western Australia. Biol Control 47:1-7

Mally CW (1924) The Eucalyptus Snout Beetle (Gonipterus scutellatus Gyll.). J Dept Agric S Africa 9:415-442

Millar JG, Paine TD, Hanks LH et al (1998) Biological control of the eucalyptus snout beetle, Gonipteras scutellatus. Slosson Report, pp. $1-3$

Morris AR (2008) Realizing the benefit of research in eucalypt plantation management. South For 70:119-129

Pass DM, Foley WJ, Bowden B (1998) Vertebrate herbivory on Eucalyptus identification of specific feeding deterrents for common ringtail possums (Pseudocheirus peregrinus) by bioassay-guided fractionation of Eucalyptus ovata foliage. J Chem Ecol 24:1513-1527

Payn KG, Dvorak WS, Myburg AA (2007) Chloroplast DNA phylogeography reveals the island colonization route of Eucalyptus urophylla (Myrtaceae). Aust J Bot 55:673-683

Rapley LP, Allen GR, Potts BM, Davies NW (2008) Constitutive or induced defences-how does Eucalyptus globulus defend itself from larval feeding? Chemoecology 17:235-243

Tooke FGC (1953) The Eucalyptus Snout-beetle, Gonipterus scutellatus Gyll. A study of its ecology and control by biological means. Entomology Memoir 3. Department of Agriculture, Pretoria, South Africa. pp. 1-26

Wingfield MJ, Slippers B, Hurley BP, Coutinho TA, Wingfield BD, Roux J (2008) Eucalypt pest and diseases: growing threats to plantation productivity. South For 70:139-144

Withers TM (2001) Colonization of eucalypts in New Zealand by Australian insects. Austral Ecol 26:467-476 